\title{
Numerical and functional responses of choreo- and oligotrich planktonic ciliates
}

\author{
Ingrid Gismervik* \\ Department of Biology, University of Oslo, PO Box 1066 Blindern, 0316 Oslo, Norway
}

\begin{abstract}
A total of 6 planktonic naked ciliates were isolated from the Oslofjord, Norway. Numerical and functional responses were investigated using bottle incubations at 11 to $14^{\circ} \mathrm{C}$, with the prasinophyceae Nephroselmis pyriformis and cryptophyceae Hemiselmis sp. as food. Growth rates followed hyperbolic curves, which levelled off at about 15000 algal cells ml ${ }^{-1}\left(152 \mu g \mathrm{C} \mathrm{l}^{-1}\right)$. Highest growth rate was recorded for the large heterotroph Strobilidium spiralis $\left(\mu_{\max }=1.38 \pm 0.08 \mathrm{~d}^{-1}(\mathrm{mean}\right.$ $\pm \mathrm{SE})$. A small mixotroph, Strombidium vestitum, displayed high growth rates $\left(\mu_{\max }=1.04 \pm 0.05 \mathrm{~d}^{-1}\right)$, compared to the larger strombidiids Strombidium conicum, $S$. acutum and Strombidium sp. $\left(\mu_{\max }=\right.$ 0.55 to $0.80 \mathrm{~d}^{-1}$ ). Food thresholds for positive net growth rates were estimated to be in the range of 600 to 3300 algal cells $\mathrm{ml}^{-1}$, or 6 to $34 \mathrm{\mu g} \mathrm{C} \mathrm{l}^{-1}$. Specific ingestion rates increased at increasing food concentrations, and maximum measured rates were generally in the range of 2 to $4 \mathrm{~d}^{-1}$. S. spiralis increased its clearance rate to a maximum of $18.3 \pm 0.69 \mu \mathrm{h}^{-1}$ as algal concentrations were enhanced from 900 to 2600 algal cells $\mathrm{ml}^{-1}$. Gross growth efficiency ranged from 7 to $52 \%$ above threshold food levels, with a mean and median of 22 and $23 \%$, respectively.
\end{abstract}

KEY WORDS: Ciliates $\cdot$ Growth rates $\cdot$ Feeding rates $\cdot$ Clearance rates $\cdot$ Threshold $\cdot$ Gross growth efficiency $\cdot$ GGE

Resale or republication not permitted without written consent of the publisher

\section{INTRODUCTION}

Ciliates are efficient grazers and a link between producers and higher trophic levels in the marine planktonic food web (Sherr \& Sherr 2002, Calbet \& Landry 2004). For convenience, members of this group are usually considered a functional entity, although important parameters like growth and feeding rates may vary considerably among related species (Montagnes 1996). Thus, closer scrutiny of species-specific differences and intra-specific differences has been called for (Weisse 2002, Weisse \& Lettner 2002). Aloricate choreotrich and oligotrich ciliates generally dominate the planktonic ciliate community at different latitudes, as well as across areas of differing trophic status, temperature and salinity (Stoecker et al. 1989, Sime-Ngando et al. 1992, Pitta et al. 2001, Nielsen \& Andersen 2002). Still, few data exist on speciesspecific numerical and functional responses for these major taxa (Jonsson 1986, Montagnes 1996, Montagnes \& Lessard 1999). Compilation of data for assess- ing general metabolic rates for planktonic ciliates often relies on a small number of data sets, or on data obtained from studies that may not be comparable (e.g. laboratory vs. field studies) (Hansen et al. 1997, Perez et al. 1997, Straile 1997). Hence the outcome of these compilations may be questionable, and it may not be accurate to assign some of these values to planktonic ciliate communities in general. For instance, the data sets on maximum ingestion and growth rates compiled by Hansen et al. (1997) only included 3 points for the common aloricate choreo- and oligotrich species, while the rest of the data were for the semi-benthic Strombidium sulcatum $(\mathrm{n}=2)$ and tintinnids $(\mathrm{n}=8)$.

Jonsson (1986) presented clearance rates for 3 ciliates species, and called for more data on the small but numerous choreotrich ciliates $(\sim 20 \mu \mathrm{m})$; however, nearly 20 yr later, species-specific data on this important component of the marine food web is still lacking. Some data exist for large species feeding on algal prey (Montagnes \& Lessard 1999, Müller \& Schlegel 1999), while the other studies have been performed using 
artificial or labelled prey (Jonsson 1986, Kivi \& Setälä 1995, Jürgens \& Šimek 2000). Measuring growth and feeding rates for ciliates on natural prey is time consuming, and some methodological problems will be encountered. While the semi-continuous technique which involves transferring single cells from well to well every day may be adequate for measuring growth rates for large ciliates, it is not a reliable method for smaller species (Montagnes 1996). Furthermore, this method gives low precision as few cells are counted ( 10 counts), and handling can increase mortality (I. Gismervik pers. obs., not shown). A method with less handling and larger cell numbers for counting is preferable; thus, I used incubation in algal culture flasks, measuring the change in cell numbers at $24 \mathrm{~h}$ intervals, a method also employed by, e.g., Jacobsen \& Hansen (1997) Müller \& Schlegel (1999) and Jürgens \& Šimek (2000). The growth rates of 6 common planktonic ciliates were examined in this study, while feeding rates were obtained for 3 of these species in separate experiments. Data from the present study are compared to previous studies on aloricate choreo- and oligotrich ciliates for which numerical and functional responses have been observed. The relationships between growth parameters and ciliate cell volume/ trophic status (mixo- vs. heterotrophy) are discussed.

\section{MATERIALS AND METHODS}

Ciliates were collected from the outer Oslofjord, Norway, on 3 occasions: in March at $5^{\circ} \mathrm{C}, 21 \%$ salinity (Strombidium conicum and $S$. acutum), in October at $13^{\circ} \mathrm{C}, 21 \%$ salinity (Strobilidium spiralis and Strombidium vestitum) and in November at $11^{\circ} \mathrm{C}, 25 \%$ salinity (Strombidium sp. and Lohmanniella oviformis). All ciliates were fed the flagellate Nephroselmis pyriformis, while $S$. spiralis was also fed Hemiselmis sp. (Table 1). Algal prey was cultured in $250 \mathrm{ml}$ glass flasks on a 12:12 h light:dark cycle at $80 \mu \mathrm{E} \mathrm{m} \mathrm{m}^{-2} \mathrm{~s}^{-1}$, and harvested in the exponential growth phase. Ciliates were cultured in 70 or $250 \mathrm{ml}$ algal culture bottles on a 12:12 h light:dark cycle at $24 \mu \mathrm{E} \mathrm{m} \mathrm{m}^{-2} \mathrm{~s}^{-1}$. Cultures were nonaxenic and kept in enriched seawater (IMR/2 medium; Eppley et al. 1967) at 25\%o salinity.

Ciliates were identified from protargol-stained samples (Montagnes \& Lynn 1993): Strombidium vestitum, S. conicum (Agatha \& Riedel-Lorjé 1997), S. acutum (Lynn \& Montagnes 1988a), Strobilidium spiralis, Lohmanniella oviformis (Lynn \& Montagnes 1988b).
Strombidium sp. (Fig. 1A) has not been previously described by protargol stains. The species was stained in this study and had 18 anterior polykinetids, 12 ventral polykinetids, a ventral kinety of 5 ciliated monokinetids, and a ciliated girdle completely surrounding the cell. The ciliate can be distinguished from other strombidiids
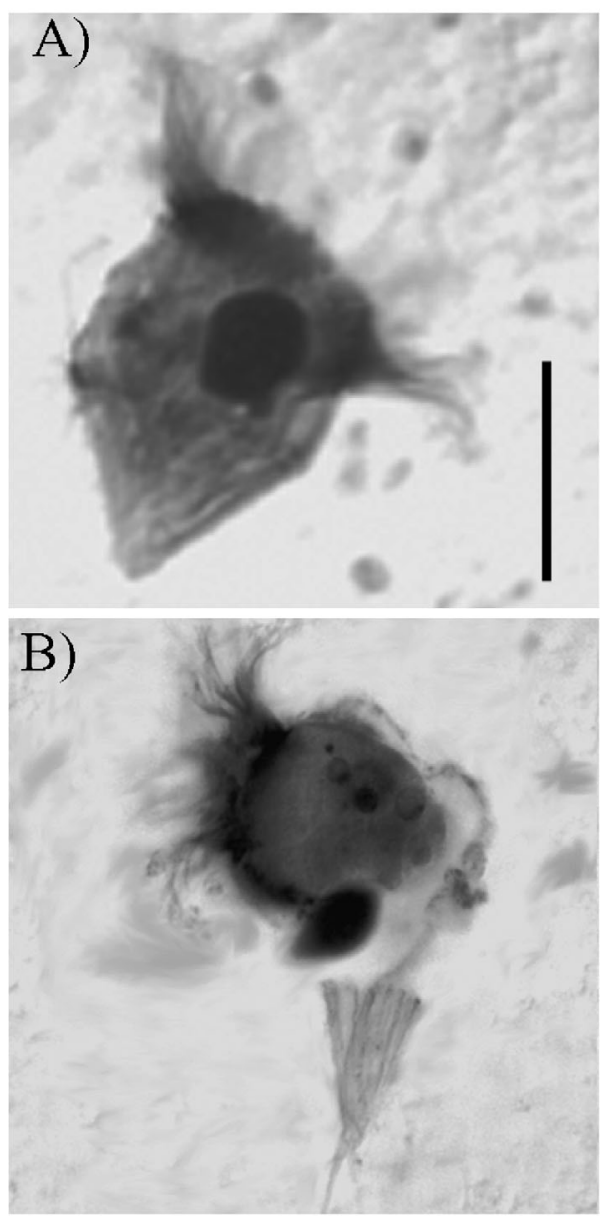

Fig. 1. Strombidium sp. (A) Intact and (B) deformed protargolstained cells. Scale bar $=20 \mu \mathrm{m}$ 
in fixed samples, as the posterior part often detaches from the rest of the cell, and the cell becomes elongated (Fig. 1B). Classification is in accordance with Lee et al. (2000). The samples were initially fixed in Lugol's iodine, then concentrated by sedimentation and diluted with Bouin's fixative to a final concentration of 5 to $10 \%$ before staining. Ciliate dimensions were obtained at $800 \times$ magnification, using a microscope equipped with a computer-aided photo digitising system.

Growth experiments were run in algal cultures bottles $(73 \mathrm{ml})$. Food algae and ciliates were gently transferred from stock cultures to the experimental bottles using a pipette; all concentrations were run in triplicate. Ciliates were generally acclimated for 24 to $48 \mathrm{~h}$. Algal concentrations were monitored every day, and after sampling 15 to $20 \mathrm{ml}$ fresh medium and algae (if necessary) were supplied. Average algal concentrations ([P]) were calculated in accordance with Frost (1972): $[\mathrm{P}]=\left(\left[\mathrm{P}_{t}\right]-\right.$ $\left.\left[\mathrm{P}_{0}\right]\right) /\left(\ln \left[\mathrm{P}_{t}\right] /\left[\mathrm{P}_{0}\right]\right)$, where $\left[\mathrm{P}_{0}\right]$ and $\left[\mathrm{P}_{t}\right]$ are start and stop concentrations of algae, respectively. Algal concentrations usually decreased during the incubation period, in general in the range of 0 to $30 \%$, but on a few occasions algal concentration was severely reduced (experiment with Strombidium acutum up to $60 \%$ decrease). Ciliate concentrations were monitored for 1 or $2 \mathrm{~d}$, and mean growth rates were calculated. Ciliates from the experiments were fixed in $2 \%$ acid Lugol's iodine and counted in Utermöhl chambers. Algal concentrations were assessed using a microscope, Coulter counter or CASY Counter.

Functional responses were determined using algal culture bottles $(40 \mathrm{ml})$ with a series of variable algal concentrations, and a constant high number of ciliates (8 to $18 \mathrm{ml}^{-1}$ ). Start samples from all bottles were retrieved after 30 to $45 \mathrm{~min}$, and incubation lasted 6 to $8 \mathrm{~h}$. A separate treatment with algae only was included to monitor algal growth. Feeding rates were calculated in accordance with Frost (1972).

All growth curves followed a hyperbolic curve. Least square fitting of the equation $\mu=\mu_{\max }\left([\mathrm{P}]-x^{\prime}\right) /(\mathrm{k}+[\mathrm{P}]$ $\left.-x^{\prime}\right)$ (Montagnes 1996), where $\mu=$ growth rate $\left(d^{-1}\right)$, $\mu_{\max }=$ maximum growth rate $\left(\mathrm{d}^{-1}\right),[\mathrm{P}]=$ algal concentration $\left(\right.$ no. $\left.\mathrm{ml}^{-1}\right), x^{\prime}=$ intercept or threshold concentration $\left(\right.$ no. $\mathrm{ml}^{-1}$ ), and $\mathrm{k}=$ constant, was performed with the non-linear fit option of the statistical programme SPlus (Insightful). For the functional response curves, the equation $I=I_{\max } \times[\mathrm{P}] /(\mathrm{k}+[\mathrm{P}])$ was used for Strombidium sp. and Lohmanniella oviformis (Type 2 response). As clearance rates seemed to increase with increasing prey densities for Strobilidium spiralis (indicating a Type 3 functional response), the equation $I=$ $I_{\max } \times\left\{([\mathrm{P}] / \mathrm{k})^{n}\right\} /\left\{1+([\mathrm{P}] / \mathrm{k})^{n}\right\}$ was chosen for this species, where $I_{\max }=$ maximum feeding rate, $\mathrm{k}=$ constant and $n=$ curve shape (Gismervik \& Andersen 1997). This equation includes a parameter, $n$, which reveals whether the data best fits a Type 3 or a Type 2 functional response.

Algal biomass was measured using a CHN analyser (Nephroselmis pyriformis, $10.1 \pm 0.005 \mathrm{pg} \mathrm{C}$ cell $^{-1}, n=$ 3; Hemiselmis sp., $23.9 \pm 0.12 \mathrm{pg} \mathrm{C}$ cell $^{-1}, \mathrm{n}=3$ ). Ciliate volume was calculated from simple geometrical formulae and converted to carbon by a factor of $0.19 \mathrm{pg} \mathrm{C}$

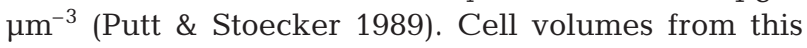
study were converted by a factor of 1.29 for comparison with studies using live volumes (Putt \& Stoecker 1989). Growth rates were normalised to $15^{\circ} \mathrm{C}$ using linear regression $\left(0.07 \mathrm{~d}^{-1}{ }^{\circ} \mathrm{C}^{-1}\right.$, Montagnes et al. 2003). Clearance rates were normalised to $15^{\circ} \mathrm{C}$ by a $Q_{10}$ of 1.6 (Verity 1985). Gross growth efficiency $(\mathrm{GGE}=\mu / I)$ was calculated from average values of $\mu\left(\mathrm{d}^{-1}\right)$ and $I$ $\left(\mathrm{d}^{-1}\right)$ at corresponding algal concentrations, and from idealised curves fitted to experimental data.

\section{RESULTS}

\section{Numerical response}

The highest growth rate was found for the heterotrophic Strobilidium spiralis (Fig. 2A). The other heterotroph of about similar length, Strombidium sp., had a considerably lower growth rate (Fig. 2C) and fell in the same range as its mixotrophic strombidiid relatives, $S$. conicum and $S$. acutum (Fig. 2D,E). The smallest mixotroph, Strombidium vestitum, on the other hand, displayed high growth rates at moderate algal concentrations (Fig. 2F). Both S. vestitum and S. conicum attained high growth rates at low levels of algal food, compared to the other species, while the lowest growth rate was displayed by Lohmanniella oviformis (Fig. 2B). The numerical responses followed a rectangular hyperbolic curve for all species, and growth parameters are given in Table 2. Estimated maximum growth rates ranged from $0.50 \pm 0.09 \mathrm{~d}^{-1}($ mean $\pm \mathrm{SE}$ ) for $L$. oviformis to $1.38 \pm 0.08 \mathrm{~d}^{-1}$ for $S$. spiralis (Table 2). The constant $\mathrm{k}$ was variable, from 1100 algal cells $\mathrm{ml}^{-1}$ for $S$. conicum to almost 9000 cells $\mathrm{ml}^{-1}$ for Strombidium sp. (Table 2). The number of algal cells required for positive net growth, $x^{\prime}$, was lowest for $S$. conicum and $S$. vestitum, at about 650 algal cells ml ${ }^{-1}$ $\left(6.5 \mu \mathrm{g} \mathrm{C} \mathrm{l}^{-1}\right)$ while the highest growth threshold $\left(\sim 3400\right.$ algal cells $\left.\mathrm{ml}^{-1}, 34 \mu \mathrm{g} \mathrm{C} \mathrm{l}^{-1}\right)$ was displayed by L. oviformis (Tables $2 \& 3$ ).

\section{Functional responses}

Strobilidium spiralis displayed high ingestion rates in terms of algal cells eaten per day, as well as high specific ingestion rates, which levelled of at $4 \mathrm{~d}^{-1}$ 

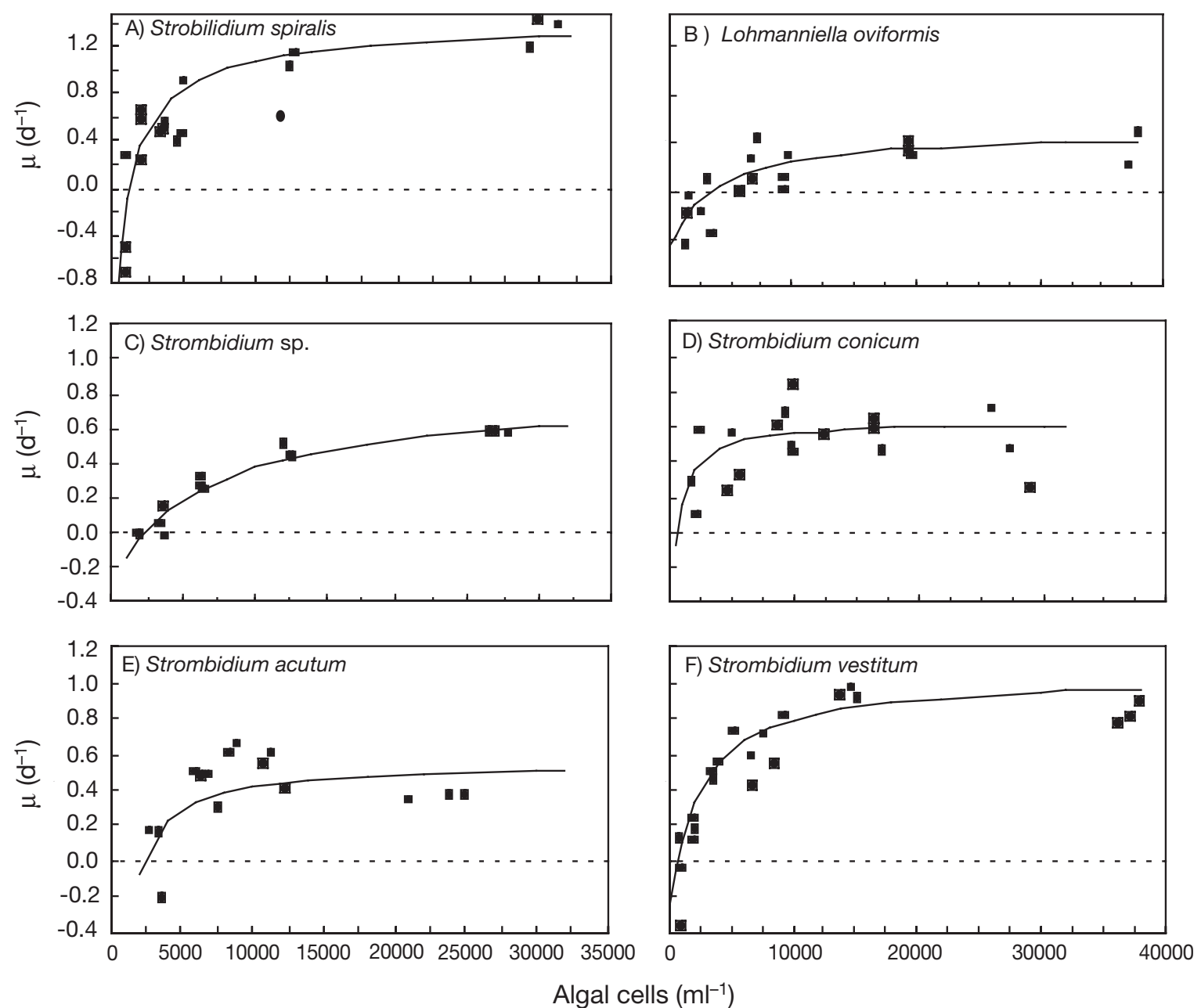

Fig. 2. Numerical responses of $(\mathrm{A}, \mathrm{B}) 2$ choreotrich ciliates and $(\mathrm{C}-\mathrm{F}) 4$ oligotrich ciliates. Symbols are measured growth rates while lines are fitted curves (see details in Table 3). The food alga was Nephroselmis pyriformis (B-F) and an equal mixture of N. pyriformis and Hemiselmis sp. (A)

(Fig. 3A). Ingestion rates were somewhat lower for Strombidium sp. (Fig. 3C), while the smaller Lohmanniella oviformis consumed considerably lower numbers of algal cells. However, specific ingestion rates for $L$. oviformis were comparable to those found for S. spiralis (Fig. 3E).

Clearance rates of Strobilidium spiralis were considerably higher than for the other 2 species (Fig. 3B,D,F), and rates increased as algal concentrations were enhanced from 900 to 2600 algal

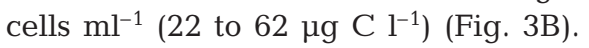
Clearance rates for Strombidium sp. and Lohmanniella oviformis seemed to decrease with increasing algal concentrations. However, data are missing
Table 2. Growth parameters for the numerical response curves fitted to data in Fig. 2, using least-square non-linear fitting option. $\mu_{\max }=$ maximum growth rate, $\mathrm{k}=$ constant, $x^{\prime}=$ intercept with $x$-axis; $95 \%$ confidence intervals given in parentheses

\begin{tabular}{|lccc|}
\hline Species & $\mu_{\max }\left(\mathrm{d}^{-1}\right)$ & $\begin{array}{c}\mathrm{k}(\mathrm{algal} \\
\left.\mathrm{cells} \mathrm{ml^{-1 }}\right)\end{array}$ & $\begin{array}{c}x^{\prime}(\mathrm{algal} \\
\left.\mathrm{cell} \mathrm{ml}^{-1}\right)\end{array}$ \\
\hline $\begin{array}{c}\text { Strombidium } \\
\text { vestitum }\end{array}$ & $1.04(0.92-1.03)$ & $2918(1753-4082)$ & $662(382-940)$ \\
$\begin{array}{c}\text { Strombidium } \\
\text { acutum }\end{array}$ & $0.55(0.37-0.73)$ & $2465(-1010-5941)$ & $2307(1359-3255)$ \\
$\begin{array}{c}\text { Strombidium } \\
\text { conicum }\end{array}$ & $0.63(0.47-0.78)$ & $1131(-826-3088)$ & $625(-429-1677)$ \\
$\begin{array}{c}\text { Strombidium } \\
\text { sp. }\end{array}$ & $0.80(0.61-0.97)$ & $8886(3559-14151)$ & $2392(1718-3072)$ \\
$\begin{array}{c}\text { Lohmanniella } \\
\text { oviformis }\end{array}$ & $0.50(0.19-0.80)$ & $6781(-349-13912)$ & $3366(1910-4821)$ \\
$\begin{array}{c}\text { Strombilidium } \\
\text { spiralis }\end{array}$ & $1.38(1.20-1.55)$ & $2384(1331-3436)$ & $1166(945-1387)$ \\
\hline
\end{tabular}



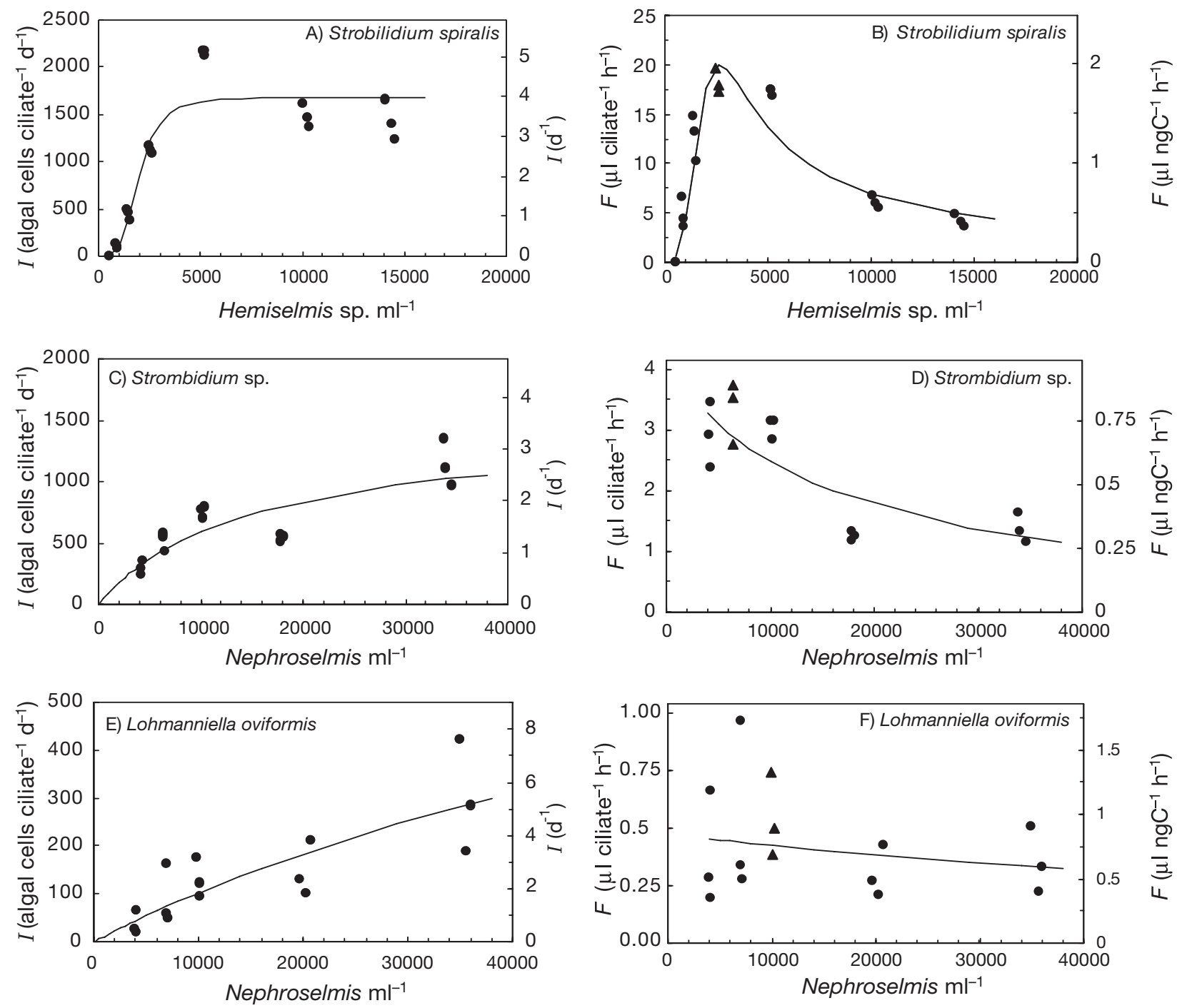

Fig. 3. Ingestion $(I)$ and clearance $(F)$ rates of $(A, B)$ Strobilidium spiralis, $(C, D)$ Strombidium sp., and $(\mathrm{E}, \mathrm{F})$ Lohmanniella oviformis. See text for details on fitted curves. $\mathbf{\Delta}$ : data points used to calculate maximum clearance rate. Note that clearance rates are given on an hourly basis

in the lower end of the food range (lowest algal concentration in the feeding experiments were about 4000

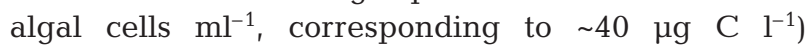
(Fig. 3D,F). Maximum clearance rates (mean $\pm \mathrm{SE}$ computed from triangles in Fig. $3 \mathrm{~B}, \mathrm{D}, \mathrm{F})$ were $0.5 \pm 0.11$,

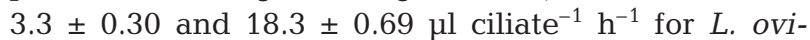
formis, Strombidium sp. and S. spiralis, respectively. In terms of specific clearance rates, $S$. spiralis $(1.81 \pm$

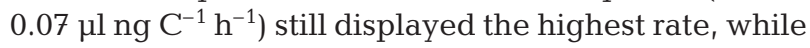
half this rate was obtained by Strombidium sp. and Lohmanniella oviformis $(0.80 \pm 0.07$ and $0.97 \pm 0.19 \mu \mathrm{l}$ $n g \mathrm{C}^{-1} \mathrm{~h}^{-1}$, respectively) (Fig. $3 \mathrm{~B}, \mathrm{D}, \mathrm{F}$ ).

Functional response curves were fitted to the data (see 'Materials and methods' for formulae), and estimated parameters for Strobilidium spiralis were $I_{\max }=$
$1676 \pm 99$ algal cells ciliate ${ }^{-1} \mathrm{~d}^{-1}(\mathrm{p}<0.0001,95 \%$ confidence limits $[C L]=1466$ to 1885$), k=1990$ algal cells $\mathrm{ml}^{-1}(\mathrm{p}<0.0001, \mathrm{CL}=1596$ to 2410$)$ and curve shape parameter of $4(p=0.003, C L=1.4$ to 6.6$)$. A curve shape parameter significantly $>1$ suggests that a Type 3 functional response curve gave the best fit. A Type 2 functional response curve was used for Strombidium sp. and Lohmanniella oviformis. $I_{\max }$ was estimated to be $1456 \pm 314$ algal cells ciliate ${ }^{-1} \mathrm{~d}^{-1}$ (mean $\pm \mathrm{SE}, \mathrm{CL}=$ 778 to $2135, \mathrm{p}<0.0001$ ) for Strombidium sp., and the constant $\mathrm{k}$ was $14578 \pm 6772$ (CL $=-52$ to $29208, \mathrm{p}=$ $0.05)$. A maximum rate of $960 \pm 1018$ algal cells ciliate ${ }^{-1}$ $\mathrm{d}^{-1}$ and a constant $\mathrm{k}$ of $84039 \pm 117239$ were established for $L$. oviformis, but none of the estimates were significant $(\mathrm{p}>0.05)$. 


\section{Gross growth efficiency}

The GGE of Strobilidium spiralis and Strombidium sp. did not differ much at food levels above $50 \mu \mathrm{g} \mathrm{Cl}^{-1}$ (values ranged from 27 to $37 \%$ ) (Fig. 4). Yield was low ( 7 to $13 \%$ ) for Lohmanniella oviformis at all food levels (Fig. 4). GGE estimates from growth $(\mu)$ and ingestion curves $(I)$ fitted in Figs. 2 \& 4 suggest that yield was quite constant at food levels above $75 \mathrm{\mu g} \mathrm{Cl}^{-1}$.

\section{DISCUSSION}

\section{Numerical response}

Species in the present study belonging to the genus Strombidium attained high $\mu_{\max }$, comparable to previously reported values (Table 3). Except for the growth rate of $S$. siculum, all reported maximum values showed a very limited range between 0.8 and $1.1 \mathrm{~d}^{-1}$ when normalised to $15^{\circ} \mathrm{C}$. For this genus, a rapid increase in growth rate to $\mu_{\max } / 2$ was observed for food levels below $50 \mu \mathrm{g} \mathrm{C} \mathrm{l}^{-1}\left(x^{\prime}+\mathrm{k}\right)$ for most species (Table 3). This swift increase in growth rates at increasing food levels corresponds with reports from micro- and mesocosm experiments, where establishment of high ciliate abundances are encountered within a week when algal concentrations are enhanced by nutrient additions and mesozooplankton levels are kept low (Gismervik et al. 2002, Lignell et al. 2003, Vadstein et al. 2004). Species of the genus Strobilidium displayed higher growth rates, and a larger span in rates than the strombidiids, with $\mu_{\max }$ ranging

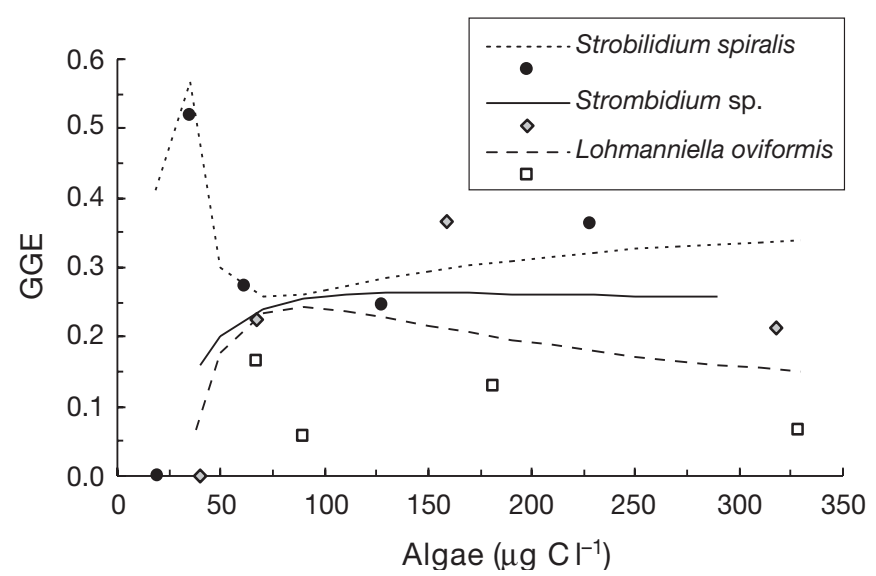

Fig. 4. Gross growth efficiency (GGE $=\mu / I)$. Lines are GGE calculated from growth and ingestion curves fitted to experimental data (Figs. 2 \& 3), while symbols are GGE calculated from average values of $\mu$ and $I(\mathrm{n}=3)$ at corresponding food levels

from 0.7 to $1.7 \mathrm{~d}^{-1}$. However, higher food levels seemed to be required in order to attain high growth rates, with $x^{\prime}+\mathrm{k}$ values generally above $50 \mu \mathrm{g} \mathrm{Cl}^{-1}$. The $\mu_{\max }$ displayed by the small Lohmanniella oviformis may have been an underestimate, as a $\mu_{\max }$ of $1.3 \mathrm{~d}^{-1}$ was obtained for this species in a parallel study of copepod impact on ciliates (I. Gismervik pers. obs.). Others studies have also shown rates for this species above $1 \mathrm{~d}^{-1}$ (Hansen \& Jensen 2000, Tang et al. 2001). Nephroselmis pyriformis seemed to be adequate food as it rendered high growth rates, low thresholds and

Table 3. Growth parameters of aloricate choreo- and oligotrich ciliates. Maximum growth rate $\left(\mu_{\max }\right.$, normalised to $15^{\circ} \mathrm{C}$ by linear regression $\left(0.07 \mathrm{~d}^{-1}{ }^{\circ} \mathrm{C}^{-1}\right.$, Montagnes et al. 2003). Cell volumes are for live cells (volumes from this study have been converted by a factor of 1.29, Putt \& Stoecker 1989). Threshold, $x^{\prime}$ and k given in carbon units, $x^{\prime}+\mathrm{k}$ is the food level at which $\mu_{\max } / 2$ is obtained

\begin{tabular}{|c|c|c|c|c|c|c|}
\hline Species & $\begin{array}{c}\text { Volume } \\
\left(\mu \mathrm{m}^{3}\right)\end{array}$ & $\begin{array}{l}\mu_{\max } \\
\left(\mathrm{d}^{-1}\right)\end{array}$ & $\begin{array}{c}\mathrm{k} \\
\left(\mu \mathrm{C} \mathrm{C} \mathrm{l}^{-1}\right)\end{array}$ & $\begin{array}{c}x^{\prime} \\
\left(\mu \mathrm{C}^{-1}\right)\end{array}$ & $\begin{array}{c}x^{\prime}+\mathrm{k} \\
\left(\mu \mathrm{C}^{-1}\right)\end{array}$ & Source \\
\hline Strombidium capitatum & 64140 & 0.97 & 242 & 271 & 513 & Montagnes (1996) \\
\hline Strombidium siculum & 28575 & 0.52 & 35 & 16 & 51 & Montagnes (1996) \\
\hline Strombidium acutum & 28686 & 0.81 & 25 & 23 & 48 & This study \\
\hline Strombidium conicum & 38299 & 0.92 & 11 & 6 & 18 & This study \\
\hline Strombidium sp. & 28420 & 1.02 & 90 & 24 & 114 & This study \\
\hline Strombidium vestitum & 8205 & 1.14 & 29 & 7 & 36 & This study \\
\hline Strombidium reticulatum & 40000 & 0.9 & 43 & 6 & 50 & Jonsson (1986) \\
\hline Strobilidium neptuni & 110000 & 1.68 & 610 & 327 & 938 & Montagnes (1996) \\
\hline Strobilidium veniliae & 19635 & 0.67 & 224 & 75 & 298 & Montagnes 1996) \\
\hline Strobilidium lacustris & 113000 & 0.96 & 160 & 61 & 220 & Müller \& Schlegel (1999) \\
\hline Lohmanniella oviformis & 3799 & 0.73 & 68 & 34 & 102 & This study \\
\hline Strobilidium spiralis & 68453 & 1.52 & 41 & 20 & 61 & This study \\
\hline Strobilidium spiralis & 150000 & 1.06 & 37 & 5 & 42 & Jonsson (1986) \\
\hline Strombidinopsis cheshiri & 92000 & 0.90 & 24 & 9 & 34 & Montagnes et al. (1996) \\
\hline Strombidinopsis multiauris & 186000 & 0.75 & 114 & 63 & 177 & Montagnes \& Lessard (1999) \\
\hline Strombidinopsis sp. & 560000 & 0.92 & 111 & 26 & 137 & Jeong et al. (1999) \\
\hline
\end{tabular}


long lived cultures despite being the only food source (except for $S$. spiralis which was fed a larger algae as well). Its size should also be optimal for ciliates ranging from the small $L$. oviformis to the larger $S$. conicum (Kivi \& Setälä 1995).

Growth rates may be affected by light conditions during incubation, and these conditions can bias the results when comparing mixo- and heterotrophic species. In this study, Strombidium acutum and S. conicum were grown in the dark, and while the growth rates of $S$. acutum were stable throughout a $6 \mathrm{~d}$ experiment, those of $S$. conicum dropped dramatically after $4 \mathrm{~d}$ (data not shown). This suggests that this species is an obligate mixotroph, and explains the high variability of the results. Hence, the rest of the experiments were performed in dim light, to ensure maximum growth of mixotrophs and moderate growth of the algal food source. Despite being grown in the dark, both $S$. conicum and $S$. acutum displayed low thresholds for positive net growth, $x^{\prime}$. Indeed, all strombidiid species investigated, with the exception of $S$. capitatum, seem to have low thresholds (Table 3). For members of the genus Strobilidium thresholds were higher than those of strombidiids, with the exception of Strobilidium spiralis (Table 3). For this species, the threshold was low, which concurred with the findings of Jonsson (1986) and Verity (1991). For the genus Strombidinopsis both low and high thresholds were encountered, but only 3 data sets were available (Table 3).

The largest heterotrophic species, Strobilidium spiralis, displayed the highest growth rate in this study, a rate that conformed well to other studies (Jonsson 1986, Hansen \& Jensen 2000), and to the fact that large species may have growth rates similar to or exceeding those of smaller ciliates (Fig. 5A, Gismervik et al. 1996, Montagnes 1996). A synthesis of growth rates between zooplankton groups reveals that specific growth rates, as well as other specific metabolic rates, decrease with increasing body size (Hansen et al. 1997). Although this may be the case when compiling data for both proto- and metazoan animals, it may not apply when specific taxonomic groups are more closely examined. For ciliates in general, there is no convincing relationship between cell size and $\mu_{\max }$ (Hansen et al. 1997), and for aloricate choreo- and oligotrich ciliates in particular there seems to be no such relationship (Fig. 5A). Thus, a growth formula for ciliates which depends on temperature and cell volume only will underestimate the growth rate of larger species (Müller \& Geller 1993).

Another question that has been raised is whether mixotrophic species have lower growth rates than strictly heterotrophic species, based on the notion that mixotrophy is costly and may be an investment in order to thrive on low food levels (Dolan \& Perez 2000). While a compilation of data by Perez et al. (1997) suggests that $\mu_{\max }$ for mixotrophs are $0.5 \mathrm{~d}^{-1}$ less than for similar sized heterotrophic species, the results by Dolan \& Perez (2000) show that both groups are able to respond to increased prey levels with rapid growth rates $\left(1.2 \mathrm{~d}^{-1}\right)$. In the present study, only data sets with complete numerical responses for planktonic ciliates
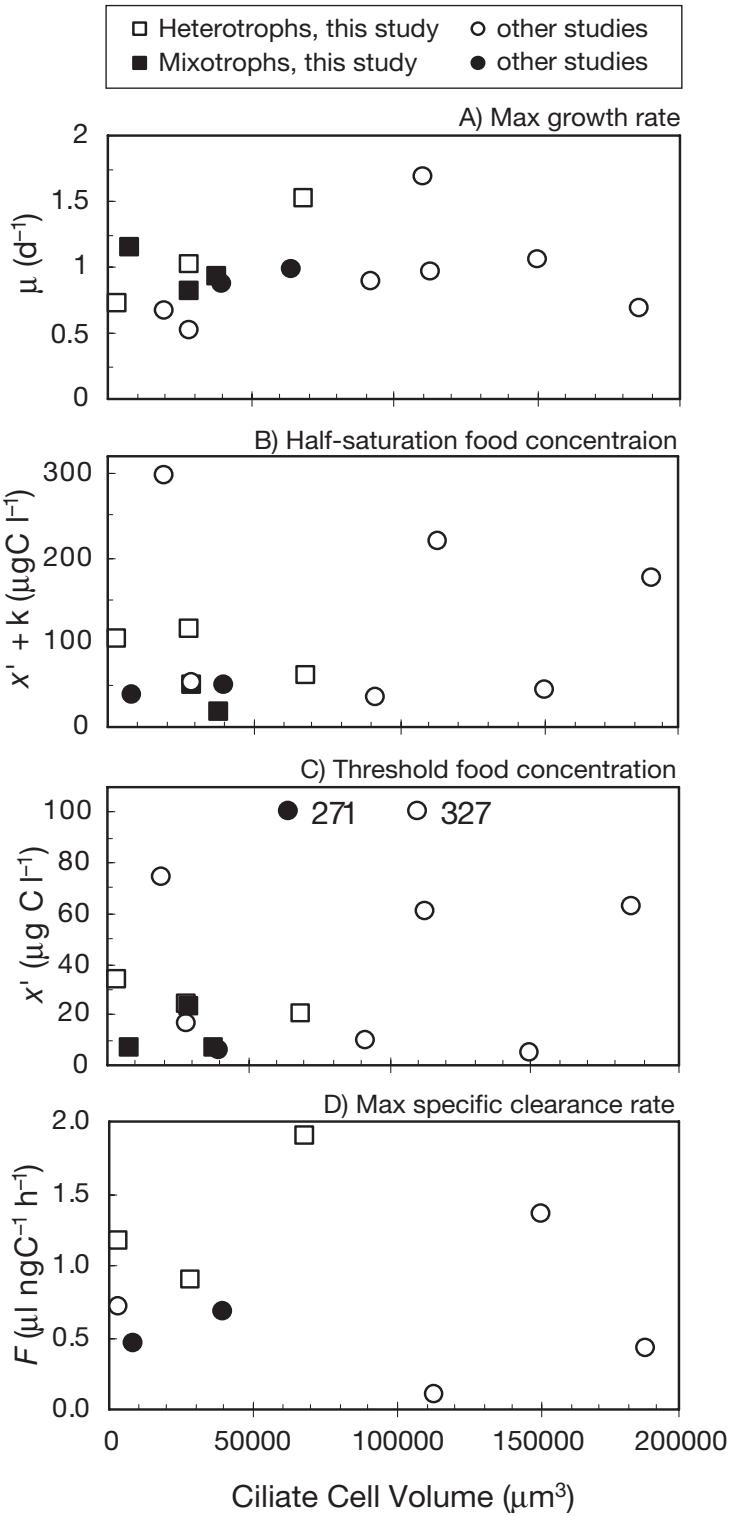

Fig. 5. (A) Maximum growth rate, (B) half-saturation food concentration, (C) threshold food concentration for positive net growth and (D) maximum specific clearance rate as a function of live volume for heterotrophic (open symbols) and mixotrophic species (filled symbols). References for other studies (circles) and cell volumes are given in Table 3 for growth rates, threshold values and half-saturation food concentrations, while clearance rates are from Jonsson (1988), Montagnes \& Lessard (1999) and Müller \& Schlegel (1999). All rates normalized to $15^{\circ} \mathrm{C}$ (see 'Materials and methods') 
feeding on algae (Strombidium sulcatum was omitted) have been included. For these data, there seems to be no pattern emerging as to whether small vs. large or hetero- vs. mixotrophic species are superior in terms of numerical response (Fig. 5A); note, however, that data are few for mixotrophic species $(n=5)$. While no differences in maximum rates are found, realised growth rates at different food levels may differ between mixoand heterotrophic species. While mixotrophic species may be adapted to low food levels, heterotrophs may need higher food levels to attain high growth rates (Dolan \& Perez 2000). $I_{\max } / 2$ is reached at a half-saturation food level of $x^{\prime}+k$ (Table 3), and data in Fig. 5B suggest that heterotrophs in general need higher food levels than mixotrophs to attain high growth rates. However, neither the half-saturation food level nor the threshold food concentration seem to be related to ciliate size (Fig. 5B,C, Hansen et al. 1997, Dolan et al. 2000). With the exception of the high threshold level recorded for Strombidium capitatum (Montagnes 1986), threshold levels for mixotrophs were low, while data for the heterotrophic species were more scattered, with half the numbers above $20 \mu \mathrm{g} \mathrm{C}^{-1}$ (Fig. 5C). Hence, trophic status may influence ciliate growth parameters more than cell size.

\section{Functional response}

Ingestion rate

Specific ingestion rates are useful for comparing differences in feeding rates between species and assessing the reliability of the data. Specific ingestion rates in this study increased with increasing food levels, and maximum rates were in the range of 2 to $4 \mathrm{~d}^{-1}$, with the exception of a few outliers. These rates are somewhat lower than the estimate of $4.8 \mathrm{~d}^{-1}$ obtained by Hansen et al. (1997) for literature data on maximum rates. However, this value was based on a compilation of data including some very high rates for the semibenthic Strombidium sulcatum and some tintinnids. Hence, it may not be representative of other pelagic ciliates. Few studies have assessed the dependency of specific ingestion rates on food concentration for aloricate choreo- and oligotrich ciliates. Rates recorded in the present study are much higher than those recorded for the larger Strobilidium lacustris and Strombidinopsis multiauris (references in Fig. 6), but in the same range as that recorded for the freshwater species Halteria cf. grandinella. The latter seem to have high ingestion rates even at very low concentrations (Fig. 6); note, however, that rates were obtained for small latex beads $(2.76 \mu \mathrm{m})$. Strobilidium spiralis showed a rapid increase in feeding rates at low food concentrations

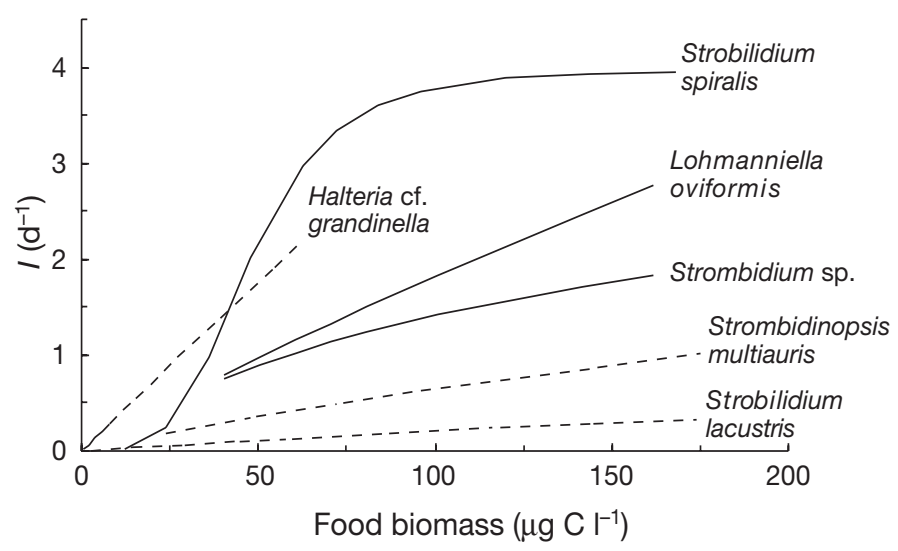

Fig. 6. Estimated specific ingestion rates (I) from this study (solid lines) and from published studies (dashed lines) (Montagnes \& Lessard 1999, Müller \& Schlegel 1999, Jürgens \& Šimek 2000; particle volume of beads converted to carbon by a factor of 0.11 , Montagnes et al. 1994)

(Fig. 6), reaching $I_{\max } / 2$ at $50 \mu \mathrm{g} \mathrm{C} \mathrm{^{-1 }}$. In contrast, the 3 other choreotrich species (Lohmanniella oviformis, $S$. lacustris and $S$. multiauris) reached $I_{\max } / 2$ at considerably higher food concentrations $\left(>800 \mu \mathrm{g} \mathrm{C}^{-1}\right)$. However, the high half-saturation constant established for L. oviformis was not significant, and may be a result of too few data at the upper end of the food range (Fig. 3E).

\section{Clearance rate}

Maximum clearance rates for ciliates were compiled by Gismervik et al. (1996), who reported a range of 0.4 to $17 \mu \mathrm{lng} \mathrm{C}^{-1} \mathrm{~h}^{-1}$ (10 to $400 \mathrm{ml} \mu \mathrm{g} \mathrm{C}^{-1} \mathrm{~d}^{-1}$ ). Ignoring the high rates of tintinnids in that compilation (which stems from one study, Verity 1985), and adding new data from Fig. 6, a median maximum clearance rate for aloricate oligotrich and choreotrich ciliates of $0.7 \mu \mathrm{lng} \mathrm{C}^{-1} \mathrm{~h}^{-1}$ (inter-quartile range of 0.5 to $1.1 \mu \mathrm{lng}$ $\mathrm{C}^{-1} \mathrm{~h}^{-1}, \mathrm{n}=10$ ) was computed. The maximum clearance rates for the 3 species in this study were in the upper range of previously reported values. The clearance rates recorded for Strobilidium spiralis were slightly lower than those recorded by Jonsson (1986) and Lessard \& Swift (1987) for this species. Likewise, the present rates recorded for Lohmanniella oviformis were somewhat lower than previously reported for fluorescently labelled algae (Chen \& Chang 1999) and starch particles (Kivi \& Setälä 1995). While experiments lasting several hours take into account the digestion of prey, this delay in feeding rate will be neglected in short-term experiments (Weisse 2002). Thus, grazing rates recorded over several hours, as in 
the present study, may give more realistic values. Some discrepancy may also be explained by different sizes of strains; the strain of $S$. spiralis used by Jonsson (1986) had an estimated cell volume of $\sim 150000 \mu^{3}$ as opposed to an estimated live volume of $\sim 68000 \mu^{3}$ in this study, while the length of L. oviformis in the study of Kivi \& Setälä (1995) was reported to be $25 \mu \mathrm{m}$, compared to $18 \mu \mathrm{m}$ in this study. However, there seems to be no clear relationship between cell size and specific clearance rates for aloricate choreo- and oligotrich ciliates (Fig. 5D). Hence, discrepancies are more likely to be a result of methodological differences.

Strobilidium spiralis reduced its feeding effort below $20 \mu \mathrm{C} \mathrm{Cl}^{-1}$, which resulted in cell shrinkage (observed in growth experiments at low algal concentration) and death. The response was confirmed by live observations: $S$. spiralis seemed rather inactive at low food concentrations. This behaviour may explain the Type 3 functional response suggested for this species, which deviates from the common perception that suspensionfeeding protozoa follow a Type 2 response. Rapid increase in both feeding and growth rates in this species as food levels increase makes it a potential key species for keeping algal abundances (within a limited size range) at a low level. While small ciliates (20 to $25 \mu \mathrm{m}, 1$ to $2 \mathrm{ng} \mathrm{C}$ cell $^{-1}$ ) make little impact on algal standing stock at abundances of $10 \mathrm{ml}^{-1}$ (abundances generally range between 1 and $10 \mathrm{ml}^{-1}$; Pierce \& Turner 1992) due to low clearance rates, large ciliates like $S$. spiralis $\left(\sim 50 \mu \mathrm{m}, 10 \mathrm{ng} \mathrm{C}\right.$ cell $\left.^{-1}\right)$ may have a profound impact at low abundances. However, its potential is hampered by the fact that it is eaten by most copepods (Broglio et al. 2001, Jakobsen 2001) and probably under tight predation control itself. Thus, the range of clearance rates obtained in this study, and knowledge of the general abundance of planktonic ciliates (Pierce \& Turner 1992, Dolan \& Perez 2000) suggest that ciliates generally make a modest contribution to grazing pressure, unless they peak in abundance due to increased food levels and reduced predation pressure. As ciliates are the dominant component of the microzooplankton, this is contradictory to the overall high rates found by the commonly used dilution technique (Landry \& Hassett 1982, Calbet \& Landry 2004). Recently, Dolan \& McKeon (2005) questioned the high and surprisingly invariant grazing rates, and suggested that microzooplankton grazing rates may have been over-estimated. When compiling data from a number of dilution experiments $(n=185)$ they found that a vast number $(n=71)$ of the studies relied on ciliates with average clearance rates $>20 \mu$ ciliate $^{-1} \mathrm{~h}^{-1}$, a number that seems very high compared to values obtained in this study. Some of the assumptions of the dilution technique may thus be violated. For instance, it is questionable that the ciliate concentration remains constant over a range of dilutions during a $24 \mathrm{~h}$ incubation when growth rate obviously depends on food availability (Fig. 2). The rate is particulary sensitive to changes at low food concentrations, and in oligotrophic systems high dilution factors may even render food concentrations below threshold food levels (Dolan et al. 2000). Although other microzooplankters like heterotrophic nanoflagellates and dinoflagellates may be important components of the microzooplankton, they are not able to account for the grazing rates obtained in the dilution studies (Dolan \& McKeon 2005).

\section{Gross growth efficiency}

By compiling literature data on GGE for ciliates, Straile (1997) found a mean and median GGE of ciliates of $30 \%$, and an inter-quartile range of 10 to $45 \%$. Other studies using volume-specific GGE report yields of more than $40 \%$ for ciliates (Rassoulzadegan 1982, Jonsson 1986, Strom \& Morello 1998, Müller \& Schlegel 1999), but these high yields may rather demonstrate the inadequacy of calculating GGE on the basis of volume than being realistic figures (Ohman \& Snyder 1991, Straile 1997, Müller \& Schlegel 1999). In the present study, the specific ingestion rates used to calculate GGE were based on measured carbon values of the algal food, but carbon values for the ciliates were calculated from volume and a conversion factor of

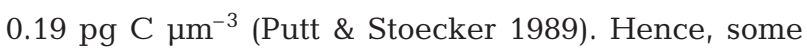
error was introduced, as ciliate cell size varies according to food availability and growth phase (Montagnes \& Lessard 1999). The GGE of Lohmanniella oviformis was low at all food levels in this study, reflecting the low growth rates obtained for this species. The yield of Strombilidium spiralis and Strombidium sp. was higher and comparable, with the exception of the high and low yield, respectively, obtained by low food concentrations. The overall mean and median values found in this study ( 22 and $23 \%$, respectively) correspond well to results obtained by Straile (1997).

Strombilidium spiralis was supplied with 2 different algae as opposed to Strombidium sp., but this seemed not to have any profound effect on the yield (comparable yield for these 2 species). However, it should be recognised that the nutritional composition of food is an important factor for GGE, together with other factors like food concentration, temperature and relative predator/prey size (Rassoulzadegan 1982, Straile 1997). The difficulties in measuring reliable growth and feeding rates at low food concentrations combined with methodological differences between studies make it hard to establish robust relationships between these parameters and GGE (Straile 1997). Food con- 
centration had the most reliable influence on GGE according to Straile (1997), but the outcome of his regression models depended highly on the data sets included and the range of food concentrations selected. In the present study, data were too few and scattered to establish any relationships between food concentration and GGE, but by using the equations for $\mu$ and $I$ based on curve fitting, it seemed that GGE levelled off above $75 \mu \mathrm{g} \mathrm{Cl}^{-1}$. At higher food concentrations (100 to $300 \mu \mathrm{g} \mathrm{C} \mathrm{l}^{-1}$ ) yield changed little for the respective species, corresponding to the pattern found by Jakobsen \& Hansen (1997) for the prostomatid Balanion comatum, and Jonsson (1986) for Strobilidium spiralis and Strombidium reticulatum.

Calculation of GGE is useful for assessing the reliability of growth and grazing data. The numerical and functional responses obtained in this study corresponded well and thus calculated GGEs were all reasonable, although at the lower end of previously reported values. However, few data exist on GGE and feeding rates for aloricate choreo- and oligotrich ciliates. In particular, data on the smaller species are still missing $(\leq 20 \mu \mathrm{m})$, and efforts should be made to establish numerical and functional responses for these important species. In future studies, the collection of reliable data at low food concentrations $\left(<50 \mu \mathrm{g} \mathrm{C}^{-1}\right)$ should be given priority.

Acknowledgements. I thank S. Brubak for preparing the protargol stains, O. Vadstein and Y. Børsheim for reading earlier drafts of the manuscript, and the referees for valuable comments.

\section{LITERATURE CITED}

Agatha S, Riedel-Lorjé JC (1997) Morphology, infraciliature, and ecology of halteriids and strombidiids (Ciliophora, Oligotrichea) from coastal brackish water basins. Arch Protistenkd 148:445-459

Broglio E, Johansson M, Jonsson PR (2001) Trophic interaction between copepods and ciliates: effects of prey swimming behaviour on predation risk. Mar Ecol Prog Ser 220:179-186

Calbet A, Landry MR (2004) Phytoplankton growth, microzooplankton grazing, and carbon cycling in marine systems. Limnol Oceanogr 49:51-57

Chen KM, Chang J (1999) Influence of light intensity on the ingestion rate of a marine ciliate, Lohmanniella sp. J Plankton Res 21:1791-1798

Dolan JR, McKeon KM (2005) The reliability of grazing rate estimates from dilution experiments: have we overestimated rates of organic carbon consumption by microzooplankton? Ocean Sci 1:1-7

Dolan JR, Pérez MT (2000) Cost, benefits and characteristics of mixotrophy in marine oligotrichs. Freshw Biol 45: $227-238$

Dolan JR, Gallegos CL, Moigis A (2000) Dilution effects on microzooplankton in dilution grazing experiments. Mar Ecol Prog Ser 200:127-139
Eppley RW, Holmes RW, Strickland JDH (1967) Sinking rates of marine phytoplankton measured with fluorometer. J Exp Mar Biol Ecol 1:191-208

Frost BW (1972) Effects of size and concentration of food particles on the feeding behaviour of the marine planktonic copepod Calanus pacificus. Limnol Oceanogr 17: 805-815

Gismervik I, Andersen T (1997) Prey switching by Acartia clausi: experimental evidence and implications of intraguild predation assessed by a model. Mar Ecol Prog Ser 157:247-259

Gismervik I, Andersen T, Vadstein O (1996) Pelagic food webs and eutrophication of coastal waters: impact of grazers on algal communities. Mar Pollut Bull 33:22-35

Gismervik I, Olsen Y, Vadstein O (2002) Micro- and mesozooplankton response to enhanced nutrient inputa mesocosm study. Hydrobiologia 484:75-87

Hansen BW, Jensen F (2000) Specific growth rates of protozooplankton in the marginal ice zone of the central Barents Sea during spring. J Mar Biol Assoc UK 80:37-44

Hansen PJ, Bjørnsen PK, Hansen BW (1997) Zooplankton grazing and growth: scaling within the $2-2000 \mu \mathrm{m}$ body size range. Limnol Oceanogr 42:687-704

Jakobsen HH (2001) Escape of protists in predator-generated feeding currents. Aquat Microb Ecol 26:271-281

Jakobsen HH, Hansen PJ (1997) Prey size selection, grazing and growth response of the small heterotrophic dinoflagellate Gymnodinium sp. and the ciliate Balanion comatum - a comparative study. Mar Ecol Prog Ser 158: $75-86$

Jeong HJ, Shim JH, Lee CW, Kim JS, Koh SM (1999) Growth and grazing rates of the marine planktonic ciliate Strombidinopsis sp. on red-tide and toxic dinoflagellate. J Eukaryot Microbiol 46:69-76

Jonsson PR (1986) Particle size selection, feeding rates and growth dynamics of marine planktonic oligotrichous ciliates (Ciliophora: Oligotrichina). Mar Ecol Prog Ser 33: 265-277

Jürgens K, Šimek K (2000) Functional response and particle size selection of Halteria cf. grandinella, a common freshwater oligotrichous ciliate. Aquat Microb Ecol 22:57-68

Kivi K, Setälä O (1995) Simultaneous measurements of food particle selection and clearance rates of planktonic oligotrich ciliates (Ciliophora: Oligotrichina). Mar Ecol Prog Ser 119:125-137

Landry MR, Hassett RP (1982) Estimating the grazing impact of marine micro-zooplankton. Mar Biol 67:283-288

Lee JJ, Leedale GF, Bradbury P (2000) An illustrated guide to the protozoa. Society of Protozoologists, Lawrence, KS

Lessard EJ, Swift E (1987) Species-specific grazing rates of heterotrophic dinoflagellates in oceanic waters, measured with a dual-label radioisotop technique. Mar Biol 87: 289-296

Lignell R, Seppälä J, Kuuppo P, Tamminen T, Andersen T, Gismervik I (2003) Beyond bulk properties: responses of coastal summer plankton communities to nutrient enrichment in the northern Baltic Sea. Limnol Oceanogr 48: 189-209

Lynn DH, Montagnes DJS (1988a) Taxonomic descriptions of some conspicuous species in the family Strombididae (Ciliophora: Oligotrichida) from the Isles of Shoals, Gulf of Maine. J Mar Biol Assoc UK 68:259-276

Lynn DH, Montagnes DJS (1988b) Taxonomic descriptions of some conspicuous species of Strobilidine ciliates (Ciliophora: Choreotrichida) from the Isles of Shoals, Gulf of Maine. J Mar Biol Assoc UK 68:639-658

Montagnes DJS (1996) Growth responses of planktonic cili- 
ates in the genera Strobilidium and Strombidium. Mar Ecol Prog Ser 130:241-254

Montagnes DJS, Lessard EJ (1999) Population dynamics of the marine planktonic ciliate Strombidinopsis multiauris: its potential to control phytoplankton blooms. Aquat Microb Ecol 20:167-181

Montagnes DJS, Lynn D (1993) A quantitative protargol stain (QPS) for ciliates and other protists. In: Kemp PF, Sherr BF, Sherr EB, Cole JJ (eds) Handbook of methods in aquatic microbial ecology. Lewis Publishers, Boca Raton, FL, p 229-240

Montagnes DJS, Kimmance SA, Atkinson D (2003) Using $Q_{10}$ : can growth rates increase linearly with temperature? Aquat Microb Ecol 32:307-313

Montagnes DJS, Berges JA, Harrison PJ, Taylor FJR (1994) Estimating carbon, nitrogen, protein and chlorophyll a from volume in marine phytoplankton. Limnol Oceanogr 40:1005-1011

Montagnes DJS, Berger JD, Taylor FJR (1996) Growth rate of the marine planktonic ciliate Strombidinopsis cheshiri Snyder and Ohman as a function of food concentration and interclonal variability. J Exp Mar Biol Ecol 206:121-132

Müller H, Geller W (1993) Maximum growth rates of aquatic ciliated protozoa - the dependence on body size and temperature reconsidered. Arch Hydrobiol 126:315-327

Müller H, Schlegel A (1999) Responses of three freshwater planktonic ciliates with different feeding modes to cryptophyte and diatom prey. Aquat Microb Ecol 17:49-60

Nielsen TG, Andersen CM (2002) Plankton community structure and production along a freshwater-influenced Norwegian fjord system. Mar Biol 141:707-724

Ohman MD, Snyder RA (1991) Growth kinetics of the omnivorous oligotrich ciliate Strombidium sp. Limnol Oceanogr 36:922-935

Pérez MT, Dolan JR, Fukai E (1997) Planktonic oligotrich ciliates in the NW Mediterranean: growth rates and consumption by copepods. Mar Ecol Prog Ser 155:89-101

Pierce RW, Turner JT (1992) Ecology of planktonic ciliates in marine food webs. Rev Aquat Sci 6:139-181

Pitta P, Giannakourou A, Christaki U (2001) Planktonic ciliates in the oligotrophic Mediterranean Sea: longitudinal trends of standing stocks, distributions and analysis of food vacuole content. Aquat Microb Ecol 24:297-311

Editorial responsibility: John Dolan, Villefranche-sur-Mer, France
Putt M, Stoecker D (1989) An experimentally determined carbon:volume ratio for marine 'oligotrichous' ciliates from estuarine coastal waters. Limnol Oceanogr 34:1097-1103

Rassoulzadegan F (1982) Dependence of grazing rate, gross growth efficiency and food size range on temperature in a pelagic oligotrichous ciliate Lohmanniella spiralis Leeg., fed on naturally occurring particulate matter. Ann Inst Océanogr 58:177-184

Sherr EB, Sherr BF (2002) Significance of predation by protists in aquatic microbial food webs. Antonie Leeuwenhoek 81:293-308

Sime-Ngando T, Juniper K, Vézina A (1992) Ciliated protozoan communities over Cobb Seamount: increase in biomass and spatial patchiness. Mar Ecol Prog Ser 89:37-51

Stoecker DK, Taniguchi A, Michaels AE (1989) Abundance of autotrophic, mixotrophic and heterotrophic ciliates in the shelf and slope waters. Mar Ecol Prog Ser 50:241-254

Straile D (1997) Gross growth efficiency of protozoan and metazoan zooplankton and their dependence on food concentration, predator-prey weight ratio, and taxonomic group. Limnol Oceanogr 42:1375-1385

Strom SL, Morello TA (1998) Comparative growth rates and yields of ciliates and heterotrophic dinoflagellates. J Plankton Res 20:571-584

Tang KW, Jakobsen HH, Visser AW (2001) Phaeocystis globosa (Prymnesiophyceae) and the planktonic food web: feeding, growth, and trophic interactions among grazers. Limnol Oceanogr 46:1860-1870

Vadstein O, Stibor H, Lippert B, Løseth K, Roederer W, SundtHansen L, Olsen Y (2004) Moderate increase in the biomass of omnivorous copepods may ease grazing control of planktonic algae. Mar Ecol Prog Ser 270:199-207

Verity PG (1985) Grazing, respiration, excretion, and growth rates of tintinnids. Limnol Oceanogr 30:1268-1282

Verity PG (1991) Measurement and simulation of prey uptake by marine planktonic ciliates fed plastidic and aplastidic nanoplankton. Limnol Oceanogr 36:729-750

Weisse T (2002) The significance of inter- and intraspecific variation in bacterivorous and herbivorous protists. Antonie Leeuwenhoek 81:327-341

Weisse T, Lettner S (2002) The ecological significance of intraspecific variation among freshwater ciliates. Verh Int Ver Limnol 28:1880-1884

Submitted: January 12, 2005; Accepted: May 2, 2005

Proofs received from author(s): August 22, 2005 